Original paper

\title{
Rapidcreekite of anthropogenic origin - 'korkinoite' from burnt mine dump in the Chelyabinsk coal basin, South Urals, Russia: crystal structure refinement, thermal behavior and spectroscopic characterization
}

\author{
Margarita S. AVDONTCEVA ${ }^{1 *}$, Andrey A. ZOLOTAREV ${ }^{1}$, Sergey V. KRIVOVICHEV 1,2 , \\ Maria G. KRZHIZHANOVSKAYA ${ }^{1}$, Vladimir N. BOCHAROV ${ }^{3}$, Vladimir V. SHILOVSKIKH ${ }^{3}$, \\ Anatoly A. ZOLOTAREV ${ }^{1}$, Mikhail A. RASSOMAKHIN ${ }^{4}$
${ }^{1}$ Institute of Earth sciences, Saint-Petersburg State University, Universitetskaya emb. 7/9, 199034, St. Petersburg, Russia; m.avdontceva@spbu.ru
${ }^{2}$ Nanomaterials Research Center, Federal Research Center, Kola Centre, Russian Academy of Sciences, 14, Fersman st., Apatity, 184209, Murmansk Region, Russia
${ }^{3}$ Centre for Geo-Environmental Research and Modelling, Saint-Petersburg State University, Ulyanovskaya st., 1, St. Petersburg, Russia
${ }^{4}$ South Urals Federal Research Center of Mineralogy and Geoecology of UB RAS, 456317 Miass, Russia
* Corresponding author

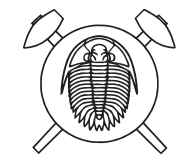

\begin{abstract}
Anthropogenic rapidcreekite, $\mathrm{Ca}_{2}\left(\mathrm{SO}_{4}\right)\left(\mathrm{CO}_{3}\right) \cdot 4 \mathrm{H}_{2} \mathrm{O}$, from burnt dumps of coal mines in the Chelyabinsk coal basin, South Urals, Russia, previously described as 'korkinoite', has been studied by single-crystal X-ray diffraction, high-temperature powder X-ray diffraction, infrared (IR) and Raman spectroscopy. The mineral is orthorhombic, Pcnb, $a=15.5334(6)$ $\AA, b=19.2379(7) \AA, c=6.1625(3) \AA, V=1841.54(13) \AA^{3}$. The crystal structure is based upon heteropolyhedral sheets parallel to (100) and can be described as produced from the crystal structure of gypsum by chemical twinning. The Ca1 and $\mathrm{Ca} 2$ sites are coordinated by six $\mathrm{O}$ atoms and two $\mathrm{H}_{2} \mathrm{O}$ molecules each. The $\mathrm{CaO}_{8}$ polyhedra form chains parallel to the $c$ axis, connected via $\mathrm{CO}_{3}$ groups and $\mathrm{SO}_{4}$ tetrahedra to form a two-dimensional arrangement. The sheets are linked to each other by means of the hydrogen bonding network. The main bands of the IR and Raman spectra correspond to symmetric and asymmetric vibrations in the $\mathrm{SO}_{4}{ }^{2-}$ tetrahedra and $\mathrm{CO}_{3}{ }^{2-}$ groups. The $\mathrm{OH}^{-}$stretching region possesses high-intensity peaks. 'Korkinoite' is stable up to $200^{\circ} \mathrm{C}$. Thermal expansion has a strong anisotropic character in the $a b$ and $b c$ planes and is almost isotropic within the $a c$ plane. The thermal expansion coefficients are approximately the same at room temperature and $200^{\circ} \mathrm{C}\left(\times 10^{-6}{ }^{\circ} \mathrm{C}^{-1}\right):\left(\alpha_{a}=53.7, \alpha_{b}=11.6 \alpha_{c}=52.0, \alpha_{v}=117.3\left(25^{\circ} \mathrm{C}\right) ; \alpha_{a}=53.2\right.$, $\alpha_{b}=11.6 \alpha_{c}=51.6, \alpha_{v}=116.4\left(200^{\circ} \mathrm{C}\right)$ ). The maximal thermal expansion is along [100] (perpendicular to the plane of the layers). Both 'korkinoite' (anthropogenic rapidcreekite) and rapidcreekite are structurally related to gypsum due to the unit-cell twinning induced by replacing one-half of sulfate groups in gypsum by carbonate ions in rapidcreekite. These structural relations determine the similarity of thermal behavior of gypsum and rapidcreekite with strongly anisotropic expansion within the sheet of $\mathrm{Ca}$ polyhedra and sulfate or sulfate and carbonate groups. The current study confirms that 'korkinoite' is identical to rapidcreekite, except for the insignificant differences in the chemical composition.
\end{abstract}

Keywords: burned coal dumps, crystal structure, thermal behavior, spectroscopic data, 'korkinoite', rapidcreekite, gypsum Received: 31 March 2021; accepted: 1 October 2021; handling editor: F. Laufek

The online version of this article (doi: 10.3190/jgeosci.327) contains supplementary electronic material.

\section{Introduction}

In burnt dumps of mines operated in the Chelyabinsk coal (lignite) basin (South Urals, Russia), minerals belonging to the chemical class of sulfates are widespread, along with silicates and oxides. It includes both well-known species such as gypsum and thenardite, and rare species, which were discovered there for the first time, e.g., efremovite, $\left(\mathrm{NH}_{4}\right)_{2} \mathrm{Mg}_{2}\left(\mathrm{SO}_{4}\right)_{3}$ (Shcherbakova and Bazhenova 1989), and godovikovite, $\left(\mathrm{NH}_{4}\right) \mathrm{Al}\left(\mathrm{SO}_{4}\right)_{2}$ (Shcherbakova et al. 1988) The last two species were approved by the International Mineralogical Association (IMA) as new minerals, along with six other species: bazhenovite, $\mathrm{Ca}_{8} \mathrm{~S}_{2}\left(\mathrm{~S}_{3}\right)\left(\mathrm{S}_{2} \mathrm{O}_{3}\right)(\mathrm{OH})_{12} \cdot 20 \mathrm{H}_{2} \mathrm{O}$ (Chesnokov et al. 1987a; Bindi et al. 2005), dmisteinbergite, $\mathrm{Ca}\left(\mathrm{Al}_{2} \mathrm{Si}_{2} \mathrm{O}_{8}\right)$ (Chesnokov et al. 1990a; Zolotarev et al. 2019a), svyatoslavite, $\mathrm{Ca}\left(\mathrm{Al}_{2} \mathrm{Si}_{2} \mathrm{O}_{8}\right)($ Chesnokov et al. 1989; Krivovichev et al. 2012), rorisite, $\mathrm{CaFCl}$ (Chesnokov et al. 1990b), srebrodolskite, $\mathrm{Ca}_{2} \mathrm{Fe}_{2} \mathrm{O}_{5}$ (Chesnokov and Bazhenova 1985), and fluorellestadite, $\mathrm{Ca}_{5}\left(\mathrm{SiO}_{4}\right)_{1.5}\left(\mathrm{SO}_{4}\right)_{1.5} \mathrm{~F}$ (Chesnokov et al. 1987b; Avdontceva et al. 2021). For a long time, the anthropogenic mineral phases found in burnt dumps of coal mines have not been considered as minerals, but the recent IMA-CNMNC recommendations allow for their 

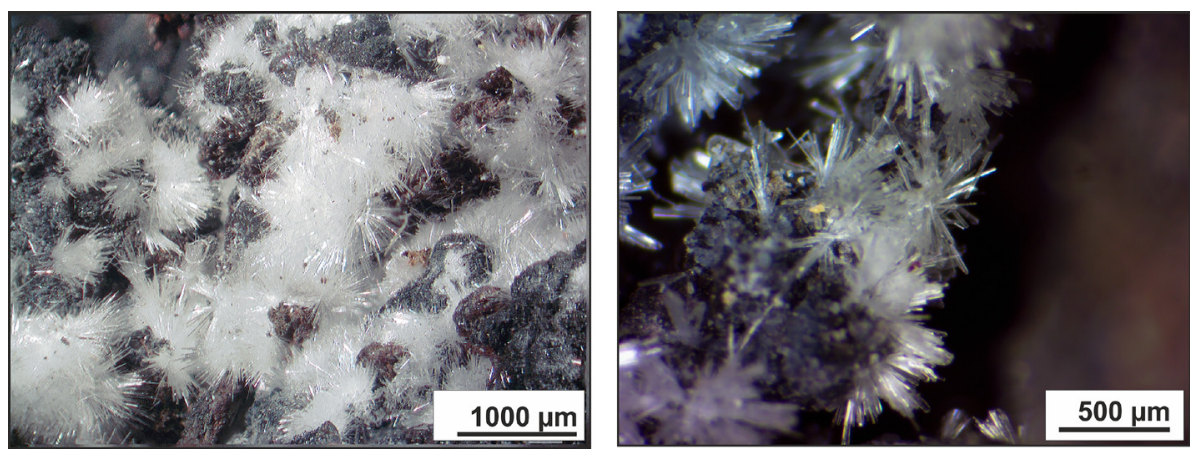

Fig. 1 Images of 'korkinoite' from Chelyabinsk coal basin as obtained under the optical microscope. status as minerals in case when the natural cause of the fire is proved (Parafiniuk and Hatert 2020).

The current work is a continuation of the series of our recent publications about the anthropogenic mineralogy of burnt dumps of coal mines in the Chelyabinsk coal basin (Zolotarev et al. 2019a, 2019b, 2020, 2021; Avdontceva et al. 2021) and is devoted to the study of crystal structure, chemical composition, thermal behavior, Raman and IR spectra of 'korkinoite', the mineral phase that was described by Chesnokov (1995) from the huge dump of the Korkinskiy open pit near the city of Korkino and the dumps of mines Nos. 45, 47 and 204 in the city of Kopeisk as a potentially new mineral with the formula $\mathrm{Ca}_{4}\left(\mathrm{SO}_{4}\right)_{2}\left(\mathrm{CO}_{3}\right)_{2} \cdot 9 \mathrm{H}_{2} \mathrm{O}$. It was found in close association with dypingite, other carbonates and also gypsum and originated in late low-temperature processes involving the activity of sulfate- and carbonate-containing vapors and solutions (Chesnokov et al. 2008). The phase is chemically related to rapidcreekite, $\mathrm{Ca}_{2}\left(\mathrm{SO}_{4}\right)\left(\mathrm{CO}_{3}\right) \cdot 4 \mathrm{H}_{2} \mathrm{O}$, which was first reported by Roberts et al. (1986) from the Rapid Creek area, Canada, from the location related to secondary mineralization of an iron deposit. The association of rapidcreekite here is almost similar to that of 'korkinoite' and includes aragonite, kulanite, gypsum, and others. Further occurrences of this mineral are connected with the U-Co mineralization in the Johann mine (Germany) and the Diana Cave (Romania), where the appearance of rapidcreekite was assigned to the activity of hot springs with the high concentrations of sulfate, calcium, chlorine and sodium. Rapidcreekite was found associated with pickeringite and other minerals of the halotrichite group, $M \mathrm{Al}_{2}\left(\mathrm{SO}_{4}\right)_{4} \cdot 22 \mathrm{H}_{2} \mathrm{O}$, where $M=\mathrm{Fe}^{2+}$, $\mathrm{Mg}, \mathrm{Mn}, \mathrm{Zn}$ or Co (Onac et al 2013). Recently the mineral was described from the weathering zone of the Lubin mine, Lower Silesia, Poland (Kruszewski et al. 2020). In general, the formation of rapidcreekite in nature is related to the low-temperature surface processes such as those occurring in hot springs (Roberts et al. 1986; Wen et al. 2020), weathering zones of ore deposits (Kruszewski et al. 2020), karst caves and springs (Onac et al. 2013; De Waele et al. 2016; D'Angeli et al. 2021) and even Arctic glaciers (Lau et al. 2017). Rapidcreekite was also found in technological environments, including pyrometal- lurgical slags (Warchulski et al. 2015), electrochemical plant sludges (Gaskova et al. 2015), cements (MartínezRamírez and Fernández-Carrasco 2012; Zhernovsky et al. 2016), and mine tailings (Situm et al. 2020).

This work aims to compare natural rapidcreekite and anthropogenic 'korkinoite' in their crystal chemistry and spectroscopic features.

\section{Materials and methods}

\subsection{Sample}

The sample of 'korkinoite' originates from the Chelyabinsk coal basin and was provided by the Natural Science Museum of the Ilmensky Reserve, Miass, Russia, from the personal collection of B.V. Chesnokov (dump of the mine No. 201, or «Tsentral'naya» in the city of Kopeisk). The mineral forms radiating sprays of transparent, colorless needle-like crystals up to $5 \mathrm{~mm}$ in length (Fig. 1).

\subsection{Chemical composition}

The chemical composition of 'korkinoite' was studied using a Hitachi S-3400N scanning electron microscope equipped with an Oxford Instruments Energy Dispersive Spectrometer X-Max 20 (20kV, $1 \mathrm{nA})$. The spectra were recorded automatically using the AzTec Energy software package using the TrueQ technique. Quantification of elemental compositions was conducted using standard samples of natural and synthetic compounds: $\mathrm{CaSO}_{4}$ for $\mathrm{Ca}, \mathrm{FeS}_{2}$ for $\mathrm{S}, \mathrm{SiO}_{2}$ for $\mathrm{Si}$ and $\mathrm{InP}$ for $\mathrm{P}$.

\subsection{Raman and Infrared spectroscopy}

The Raman spectrum of 'korkinoite' was recorded employing Horiba Jobin-Yvon LabRam HR800 spectrometer using $\mathrm{Ar}^{+}$laser with $\lambda=514.5 \mathrm{~nm}$ (power on the sample $8 \mathrm{~mW}$ ) and $50 \times$ objective. The sample was oriented randomly and measured at room temperature. The data were recorded in the range of $4000-70 \mathrm{~cm}^{-1}$. 
The calibration was carried out using Si standard $\left(520.7 \mathrm{~cm}^{-1}\right)$. The IR spectrum was obtained using Bruker Vertex 70 FTIR spectrometer with the $\mathrm{KBr}$ pellet method $(0.2 \mathrm{~g}$ of $\mathrm{KBr}$ and $0.002 \mathrm{~g}$ of the sample).

\subsection{High-temperature powder X-ray diffraction}

Thermal behavior of 'korkinoite' was studied in the air by powder high-temperature X-ray diffraction (HTXRD) method using a Rigaku Ultima IV $\left(\mathrm{Co}_{\alpha}\right.$ radiation, $40 \mathrm{kV} / 30 \mathrm{~mA}$, BraggBrentano geometry, PSD D-Tex Ultra) diffractometer with a high-temperature attachment in the temperature range of $25-850{ }^{\circ} \mathrm{C}$ with the $25^{\circ} \mathrm{C}$ steps. A thin powder sample of 'korkinoite' was deposited on a Pt sample holder $\left(20 \times 12 \times 2 \mathrm{~mm}^{3}\right)$ from an ethanol suspension.

The unit-cell parameters for all temperatures were refined by the Rietveld method using the program Topas 4.2 (Bruker 2009). The background was modeled by a Chebyshev polynomial approximation of the $16^{\text {th }}$ order. The calculation of the thermal expansion tensor and visualization of the figure of thermal expansion coefficients were done using the TEV program (Langreiter and Kahlenberg 2015).

\subsection{Single-crystal X-ray diffraction}

The single crystal of 'korkinoite' was studied using Rigaku XtaLab Synergy-S diffractometer equipped with high-speed directaction detector HyPix-6000HE. The study was carried out utilizing microfocus monochromatic Mo $K_{\alpha}$ radiation $(\lambda=0.71073$ $\AA$ ) with frame widths $0.5^{\circ}$ in $\omega$ and $10 \mathrm{~s}$ counting time for each frame. The data were interpolated into the CrysAlisPro software (2015) for further processing. An absorption correction was introduced using the SCALE3 ABSPACK algorithm. The crystal structure was solved (BVS) for 'korkinoite'.
Tab. 1 Crystallographic data and structure refinement parameters for 'korkinoite'.

\begin{tabular}{ll}
\hline Crystal system & Orthorhombic \\
Space group & Pcnb \\
$a(\AA)$ & $15.5334(6)$ \\
$b(\AA)$ & $19.2379(7)$ \\
$c(\AA)$ & $6.1625(3)$ \\
$V\left(\AA^{3}\right)$ & $1841.5(1)$ \\
$Z$ & 8 \\
$\rho_{\text {calc. }}\left(\mathrm{g} \mathrm{cm}^{-3}\right)$ & 2.224 \\
$\mu\left(\mathrm{mm}^{-1}\right)$ & 1.531 \\
$F(000)$ & 1264.0 \\
Crystal size $(\mathrm{mm})$ & $0.35 \times 0.15 \times 0.05$ \\
Radiation $(\AA)$ & MoK $K_{\alpha}(\lambda=0.71073)$ \\
$2 \Theta$ range for data collection $\left({ }^{\circ}\right)$ & $6.74-59.99$ \\
Miller-indices range & $-21 \leq h \leq 21,-27 \leq k \leq 26,-8 \leq l \leq 6$ \\
Reflections collected & 12352 \\
Independent reflections & $2687\left[R_{\text {int }}=0.0474, R_{\text {sigma }}=0.0440\right]$ \\
Data/restraints/parameters & $2687 / 8 / 164$ \\
Goodness-of-fit on $F^{2}$ & 1.069 \\
Final $R$ indexes $[I>2 \sigma(\mathrm{I})]$ & $R_{1}=0.0400, w R_{2}=0.0919$ \\
Final $R$ indexes [all data] & $R_{1}=0.0517, w R_{2}=0.0965$ \\
Largest diff. peak/hole $\left(\mathrm{e} \AA^{-3}\right)$ & $0.51 /-0.51$
\end{tabular}

by direct methods and refined by least-square techniques in the orthorhombic space group Pcnb to $R_{1}=0.040\left(w R_{2}=\right.$ $0.0965)$ for 2687 unique observed reflections with $I \geq 2 \sigma(I)$ using Shelx program package (Sheldrick 2015) within Olex2 shell (Dolomanov et al. 2009). The H positions were refined with some restrictions: thermal displacement parameters were fixed for HW1A, HW1B, HW3B, and HW4B. Crystal data and structure refinement information for 'korkinoite' are shown in Tab. 1, atomic coordinates, equivalent isotropic and anisotropic displacement parameters and bond-valence sums for each position are shown in Tab. 2 and Tab. 3, respectively. Selected interatomic distances are given in Tab. 4, hydrogen atom coordinates

Tab. 2 Atomic coordinates as well as isotropic displacement parameters $\left(\AA^{2}\right)$ and bond-valence sums

\begin{tabular}{lccccc}
\hline Atom & $x$ & $y$ & $z$ & BVS* & $U_{e q}$ \\
\hline Ca1 & $0.3341(1)$ & $0.2896(1)$ & $0.2010(1)$ & 2.12 & $0.0124(2)$ \\
Ca2 & $0.3275(1)$ & $0.0533(1)$ & $0.1889(1)$ & 2.22 & $0.0118(2)$ \\
S & $0.1686(1)$ & $0.4193(1)$ & $0.0270(1)$ & 6.00 & $0.0115(2)$ \\
C & $0.1909(2)$ & $0.1733(2)$ & $0.4341(6)$ & 4.00 & $0.0115(8)$ \\
O1 & $0.2244(2)$ & $0.3583(2)$ & $0.0488(5)$ & 2.04 & $0.0199(4)$ \\
O2 & $0.2133(2)$ & $0.2328(2)$ & $0.3566(5)$ & 1.89 & $0.0157(3)$ \\
O3 & $0.3898(2)$ & $0.4040(1)$ & $0.3420(3)$ & 1.67 & $0.0180(4)$ \\
O4 & $0.3708(2)$ & $0.1712(2)$ & $0.0748(3)$ & 1.81 & $0.0147(3)$ \\
O5 & $0.2287(1)$ & $0.1171(1)$ & $0.3825(3)$ & 2.09 & $0.0190(4)$ \\
O6 & $0.2815(2)$ & $0.4829(2)$ & $0.4840(5)$ & 2.02 & $0.0171(4)$ \\
O7 & $0.1178(1)$ & $0.4326(1)$ & $0.2242(3)$ & 1.73 & $0.0199(4)$ \\
OW1 & $0.0891(1)$ & $0.2389(1)$ & $0.0112(3)$ & 0.27 & $0.0222(4)$ \\
OW2 & $0.0481(1)$ & $0.3224(1)$ & $0.4664(4)$ & 0.30 & $0.0240(4)$ \\
OW3 & $0.0749(2)$ & $0.0204(1)$ & $0.3966(5)$ & 0.28 & $0.0205(4)$ \\
OW4 & $0.4336(1)$ & $0.0909(1)$ & $0.4675(3)$ & 0.24 & $0.0237(4)$ \\
\hline
\end{tabular}

*bond-valence sums were calculated using the bond-valence parameters from (Brese and O'Keeffe 1991). 
and isotropic displacement parameters in Tab. 5 and information about hydrogen bonds are given in Tab. 6.

Tab. 3 Anisotropic displacement parameters $\left(\AA^{2}\right)$ for 'korkinoite'.

\begin{tabular}{llllrrr}
\hline Atom & \multicolumn{1}{c}{$U^{I I}$} & \multicolumn{1}{c}{$U^{2 I}$} & \multicolumn{1}{c}{$U^{33}$} & \multicolumn{1}{c}{$U^{23}$} & \multicolumn{1}{c}{$U^{I 3}$} & \multicolumn{1}{c}{$U^{I 2}$} \\
\hline Ca1 & $0.0118(2)$ & $0.0094(2)$ & $0.0158(2)$ & $-0.0007(2)$ & $-0.0002(2)$ & $-0.0006(3)$ \\
Ca2 & $0.0122(2)$ & $0.0092(2)$ & $0.0143(2)$ & $0.0010(2)$ & $0.0003(2)$ & $0.0005(2)$ \\
S & $0.0121(3)$ & $0.0078(2)$ & $0.0148(3)$ & $-0.0008(2)$ & $-0.0001(2)$ & $-0.0000(2)$ \\
C & $0.012(1)$ & $0.0096(9)$ & $0.0131(11)$ & $0.0012(8)$ & $-0.0017(8)$ & $-0.0004(7)$ \\
O1 & $0.022(1)$ & $0.0125(8)$ & $0.025(1)$ & $0.0002(7)$ & $-0.0030(7)$ & $-0.0019(6)$ \\
O2 & $0.0175(8)$ & $0.0093(7)$ & $0.0201(9)$ & $0.0022(6)$ & $0.0030(7)$ & $-0.0019(6)$ \\
O3 & $0.0178(8)$ & $0.0148(8)$ & $0.021(1)$ & $-0.0030(7)$ & $0.0062(7)$ & $-0.0004(6)$ \\
O4 & $0.0132(8)$ & $0.0126(7)$ & $0.0183(9)$ & $0.0010(6)$ & $-0.0040(7)$ & $0.0012(6)$ \\
O5 & $0.0239(9)$ & $0.0112(7)$ & $0.0219(9)$ & $0.0010(7)$ & $0.0087(8)$ & $0.0037(6)$ \\
O6 & $0.0190(8)$ & $0.0119(7)$ & $0.0204(9)$ & $-0.0014(6)$ & $-0.0047(7)$ & $0.0049(6)$ \\
O7 & $0.0216(9)$ & $0.0169(8)$ & $0.021(1)$ & $-0.0029(7)$ & $0.0072(8)$ & $-0.0037(7)$ \\
OW1 & $0.023(1)$ & $0.0214(9)$ & $0.022(1)$ & $0.0008(8)$ & $-0.0006(8)$ & $-0.0013(7)$ \\
OW2 & $0.0172(9)$ & $0.0238(9)$ & $0.031(1)$ & $0.0059(8)$ & $-0.0039(8)$ & $0.0004(7)$ \\
OW3 & $0.0214(9)$ & $0.0183(9)$ & $0.028(1)$ & $-0.0029(7)$ & $-0.0006(8)$ & $-0.0012(7)$ \\
OW4 & $0.0183(9)$ & $0.025(1)$ & $0.021(1)$ & $0.0036(8)$ & $-0.0033(9)$ & $-0.0018(7)$ \\
\hline
\end{tabular}

Tab. 4 Selected bond-lengths (in $\AA$ ) in the crystal structure of 'korkinoite'.

\begin{tabular}{llllll}
\hline $\mathrm{Ca} 1-\mathrm{O} 1$ & $2.353(2)$ & $\mathrm{Ca} 2-\mathrm{O} 5$ & $2.299(2)$ & $\mathrm{S} 1-\mathrm{O} 1$ & $1.464(2)$ \\
$\mathrm{Ca} 1-\mathrm{O} 2$ & $2.373(2)$ & $\mathrm{Ca} 2-\mathrm{O} 5$ & $2.415(2)$ & $\mathrm{S} 1-\mathrm{O} 6$ & $1.472(2)$ \\
$\mathrm{Ca} 1-\mathrm{OW} 2$ & $2.416(2)$ & $\mathrm{Ca} 2-\mathrm{O} 6$ & $2.416(2)$ & $\mathrm{S} 1-\mathrm{O} 7$ & $1.472(2)$ \\
$\mathrm{Ca} 1-\mathrm{OW} 1$ & $2.455(2)$ & $\mathrm{Ca} 2-\mathrm{OW} 3$ & $2.439(2)$ & $\mathrm{S} 1-\mathrm{O} 3$ & $1.487(2)$ \\
$\mathrm{Ca} 1-\mathrm{O} 4$ & $2.471(2)$ & $\mathrm{Ca} 2-\mathrm{O} 4$ & $2.470(2)$ & $<\mathrm{S}-\mathrm{O}>$ & 1.474 \\
$\mathrm{Ca} 1-\mathrm{O} 2$ & $2.497(2)$ & $\mathrm{Ca} 2-\mathrm{OW} 4$ & $2.488(2)$ & & \\
$\mathrm{Ca} 1-\mathrm{O} 3$ & $2.520(2)$ & $\mathrm{Ca} 2-\mathrm{O} 6$ & $2.530(2)$ & $\mathrm{C} 1-\mathrm{O} 5$ & $1.270(3)$ \\
$\mathrm{Ca} 1-\mathrm{O} 1$ & $2.679(2)$ & $\mathrm{Ca} 2-\mathrm{O} 7$ & $2.531(2)$ & $\mathrm{C} 1-\mathrm{O} 2$ & $1.289(3)$ \\
$<\mathrm{Ca} 1-\mathrm{O}, \mathrm{O}_{\mathrm{OW}}>$ & 2.470 & $<\mathrm{Ca} 2-\mathrm{O}, \mathrm{O}_{\mathrm{OW}}>$ & 2.445 & $\mathrm{C} 1-\mathrm{O} 4$ & $1.294(3)$ \\
& & & $<\mathrm{C}-\mathrm{O}>$ & 1.284 \\
\hline
\end{tabular}

$\mathrm{O}_{\mathrm{OW}}-\mathrm{H}_{2} \mathrm{O}$ molecule as a ligand

Tab. 5 Hydrogen atoms coordinates and isotropic displacement parameters (in $\AA^{2}$ ) for 'korkinoite'

\begin{tabular}{lcccl}
\hline Atom & $x$ & $y$ & $z$ & \multicolumn{1}{c}{$U_{\text {eq }}$} \\
\hline HW1A & $0.113(3)$ & $0.252(3)$ & $0.128(5)$ & 0.050 \\
HW1B & $0.091(3)$ & $0.1951(6)$ & $-0.007(7)$ & 0.050 \\
HW2A & $-0.0048(9)$ & $0.322(2)$ & $0.498(7)$ & $0.046(12)$ \\
HW2B & $0.062(2)$ & $0.358(1)$ & $0.397(6)$ & $0.050(1)$ \\
HW3A & $0.090(2)$ & $-0.017(1)$ & $0.338(6)$ & $0.046(11)$ \\
HW3B & $0.078(3)$ & $0.050(2)$ & $0.297(5)$ & 0.050 \\
HW4A & $0.490(1)$ & $0.870(30)$ & $0.449(9)$ & $0.038(16)$ \\
HW4B & $0.486(1)$ & $0.070(2)$ & $0.588(3)$ & 0.050 \\
\hline
\end{tabular}

Tab. 6 Hydrogen bonds in the crystal structure of 'korkinoite'.

\begin{tabular}{lccccl}
\hline$D-\mathrm{H}$ & $d(D-\mathrm{H})$ & $d(\mathrm{H} \ldots \mathrm{A})$ & $<D \mathrm{H} A>$ & $d(D \ldots A)$ & \multicolumn{1}{c}{$A$} \\
\hline OW1-HW1A & 0.849 & 2.134 & 145.78 & 2.876 & O2 \\
OW1-HW1B & 0.851 & 2.046 & 166.80 & 2.881 & OW4 \\
OW2-HW2A & 0.844 & 1.994 & 175.18 & 2.836 & O4 \\
OW2-HW2B & 0.846 & 1.975 & 168.46 & 2.809 & O7 \\
OW3-HW3A & 0.849 & 1.899 & 168.05 & 2.735 & O3 \\
OW3-HW3B & 0.840 & 2.185 & 156.80 & 2.976 & OW4 \\
OW4-HW4A & 0.848 & 2.006 & 173.25 & 2.850 & O3 \\
OW4-HW4B & 0.843 & 2.135 & 174.84 & 2.976 & OW3 \\
\hline
\end{tabular}

$D$-donor; $A$ - acceptor
All research studies were carried out in the Research centers of St. Petersburg State University ( «Geomodel» (Raman spectroscopy and chemical composition); $\mathrm{X}$-Ray diffraction Centre (single-crystal X-ray diffraction studies, IR spectroscopy and high-temperature X-ray diffraction)).

\section{Results and discussion}

\subsection{Chemical composition}

The chemical formula of 'korkinoite' was calculated on the basis of $\mathrm{Ca}+\mathrm{S}+\mathrm{C}=4$, the $\mathrm{H}_{2} \mathrm{O}$ amount was determined from the structure refinement. The average composition and the value range (wt. \%) are the following: Ca 36.05 (35.3237.36), $\mathrm{SO}_{3} 26.5$ (25.39-27.03), $\mathrm{SiO}_{2} 0.18(0-0.53), \mathrm{P}_{2} \mathrm{O}_{5} 0.11$ (0-0.42), $\mathrm{CO}_{2 \text { calc }} 13.39, \mathrm{H}_{2} \mathrm{O}_{\text {calc }}$ 23.11, total 99.34. The empirical formula, $\mathrm{Ca}_{2.01}\left(\mathrm{SO}_{4}\right)_{1.03}\left(\mathrm{SiO}_{4}\right)_{0.01}$ $\left(\mathrm{PO}_{4}\right)_{0.01}\left(\mathrm{CO}_{3}\right)_{0.95} \cdot 4 \mathrm{H}_{2} \mathrm{O}$, is in good agreement with the ideal formula of rapidcreekite, $\mathrm{Ca}_{2}\left(\mathrm{SO}_{4}\right)\left(\mathrm{CO}_{3}\right) \cdot 4 \mathrm{H}_{2} \mathrm{O}$. The comparison of 'korkinoite' with rapidcreekite from different localities shows that the content of the main components is almost the same and varies only slightly. The slight differences in the chemical composition are related to the locality and the paragenetic mode of mineral formation. For instance, rapidcreekite from Diana Cave, which crystallized from hot springs of $\mathrm{H}_{2} \mathrm{~S}$-rich thermomineral water, shows partial isomorphic replacement of $\mathrm{Ca}$ by $\mathrm{Na}\left(\mathrm{Na}_{2} \mathrm{O} 0.291\right.$ wt. \%) and $\mathrm{Mg}(\mathrm{MgO} 0.173$ wt. \%). In contrast, rapidcreekite from the Rapid Creek area contains insignificant amounts of $\mathrm{Cl}(0.09$ 


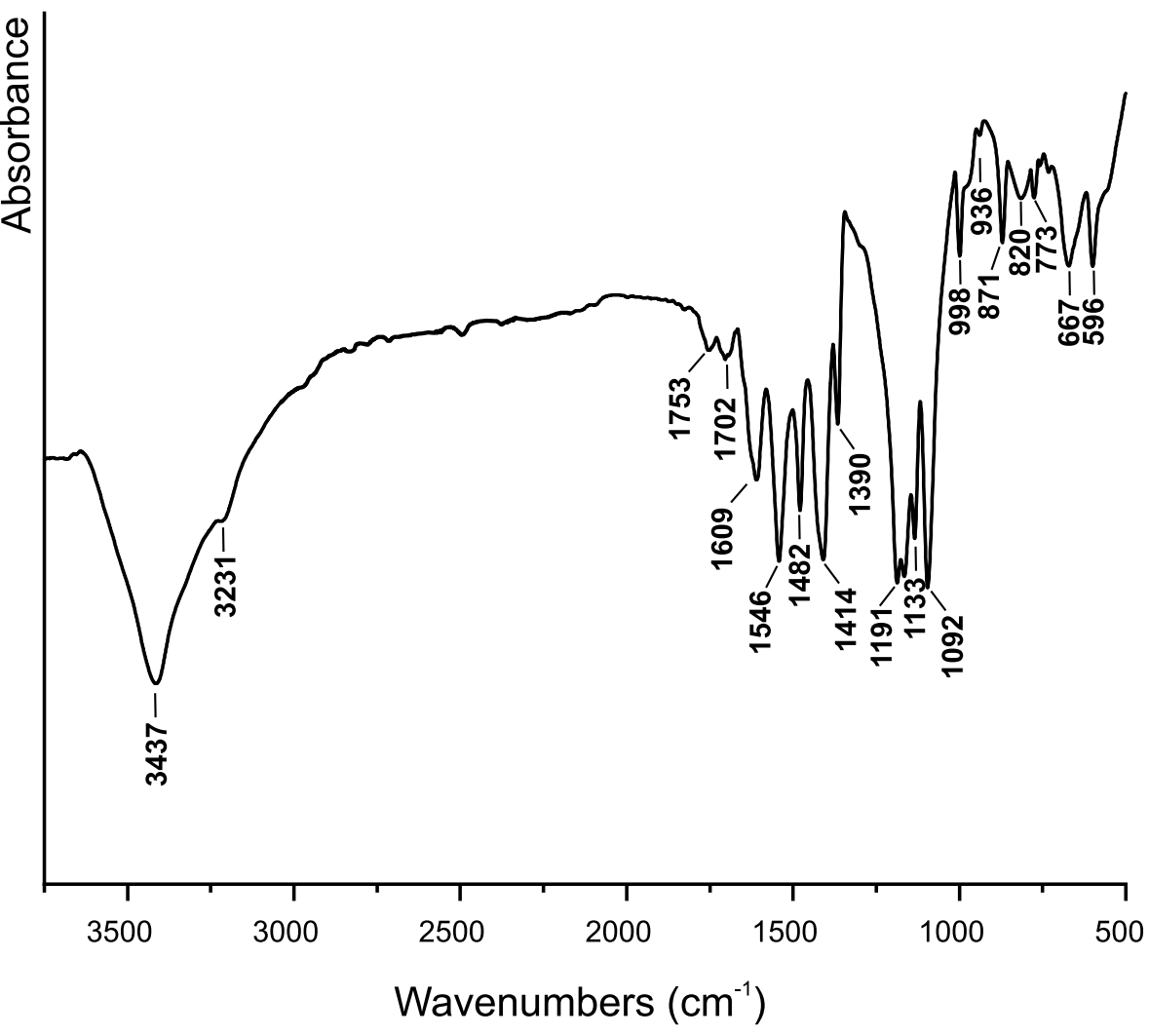

Fig. 2 Infrared spectrum of 'korkinoite' $\left(3750-500 \mathrm{~cm}^{-1}\right)$.

wt. \%), F (0.03 wt. \%), $\mathrm{PO}_{4}\left(0.07\right.$ wt. \%) and $\mathrm{NO}_{3}(0.15$ wt. \%) (Roberts et al. 1986).

\subsection{Infrared and Raman spectra}

IR spectrum of 'korkinoite' is shown in Fig. 2 and is very similar to the spectrum of rapidcreekite obtained by Roberts et al. (1986). The region of O-H stretching vibrations is characterized by the strong band at $3437 \mathrm{~cm}^{-1}$ and the weak shoulder at $3231 \mathrm{~cm}^{-1}$. The medium band at $1609 \mathrm{~cm}^{-1}$ due to bending vibration of water. The existence of $\mathrm{CO}_{3}{ }^{2-}$ groups is confirmed by three strong asymmetric stretching bands $\left(v_{3}\right)$ at 1546, 1414 and $1482 \mathrm{~cm}^{-1}$, respectively. Two medium and weak bands at 871 and $820 \mathrm{~cm}^{-1}$ can be assigned to symmetric $\mathrm{O}-\mathrm{C}-\mathrm{O}$ bending vibrations $\left(v_{2}\right)$, whereas asymmetric bending vibrations $\left(v_{4}\right)$ are manifested by the weak band at $667 \mathrm{~cm}^{-1}$. The weak bands at 1753 and $1702 \mathrm{~cm}^{-1}$ can be assigned to $\left(v_{1}+v_{4}\right)$ vibrations of $\mathrm{CO}_{3}{ }^{2-}$ groups (Brooker et al. 1983; Ibáñez-Insa et al. 2017).

The very strong bands at 1092 and $1191 \mathrm{~cm}^{-1}$, and a strong band at $1133 \mathrm{~cm}^{-1}$ have been assigned to asymmetric stretching vibrations $\left(v_{3}\right)$ of $\mathrm{SO}_{4}{ }^{2-}$ tetrahedra, whereas symmetric stretching vibrations correspond to the weak bands at 998 and $936 \mathrm{~cm}^{-1}$. Asymmetric bending vibrations of $\mathrm{O}-\mathrm{S}-\mathrm{O}$ are manifested by the weak band at 773 $\mathrm{cm}^{-1}$ (Lane 2007).
The medium band at $1390 \mathrm{~cm}^{-1}$ could be attributed to the stretching vibrations of $\mathrm{NO}_{3}$ groups of $\mathrm{KNO}_{3}$, a common admixture in $\mathrm{KBr}$ used for pellets.

The most high-intensity bands of the Raman spectrum of 'korkinoite' (Fig. 3) correspond to symmetric stretching modes of $\mathrm{SO}_{4}\left(1001 \mathrm{~cm}^{-1}\right)$ and $\mathrm{CO}_{3}{ }^{2-}\left(1083 \mathrm{~cm}^{-1}\right)$ groups. Two bands of the medium intensity at 412 and $490 \mathrm{~cm}^{-1}$ are related to symmetric bending $v_{2}$ vibrations in sulfate tetrahedra. Low-intensity bands at 607 and 667 $\mathrm{cm}^{-1}$ can be assigned to asymmetric $v_{4}$ vibration in $\mathrm{SO}_{4}$ tetrahedra or $\mathrm{CO}_{3}$ planar groups. Asymmetric stretching vibrations correspond to the low-intensity bands at 1130 $\mathrm{cm}^{-1}, 1172 \mathrm{~cm}^{-1}\left(\mathrm{SO}_{4}{ }^{2-}\right)$ and $1459 \mathrm{~cm}^{-1}\left(\mathrm{CO}_{3}{ }^{2-}\right)$. A band at $733 \mathrm{~cm}^{-1}$ is possibly connected with the $v_{2}$ mode of $\mathrm{CO}_{3}{ }^{2-}$ groups.

The $\mathrm{O}-\mathrm{H}$ band region is less intense than in the IR spectrum but also confirms the existence of a significant amount of $\mathrm{H}_{2} \mathrm{O}$ (band at $3340 \mathrm{~cm}^{-1}$ with a weak shoulder at $\left.3397 \mathrm{~cm}^{-1}\right)$. Lattice modes are related to the bands below $300 \mathrm{~cm}^{-1}$ (Brooker et al. 1983; Frezzotti et al. 2012).

\subsection{Crystal structure}

The crystal structure refinement confirms the identity of 'korkinoite' with rapidcreekite (Cooper and Hawthorne 1996; Onac et al. 2013).

The crystal structure is layered and based on heteropolyhedral sheets parallel to (100) (Fig. 4a). The Ca1 


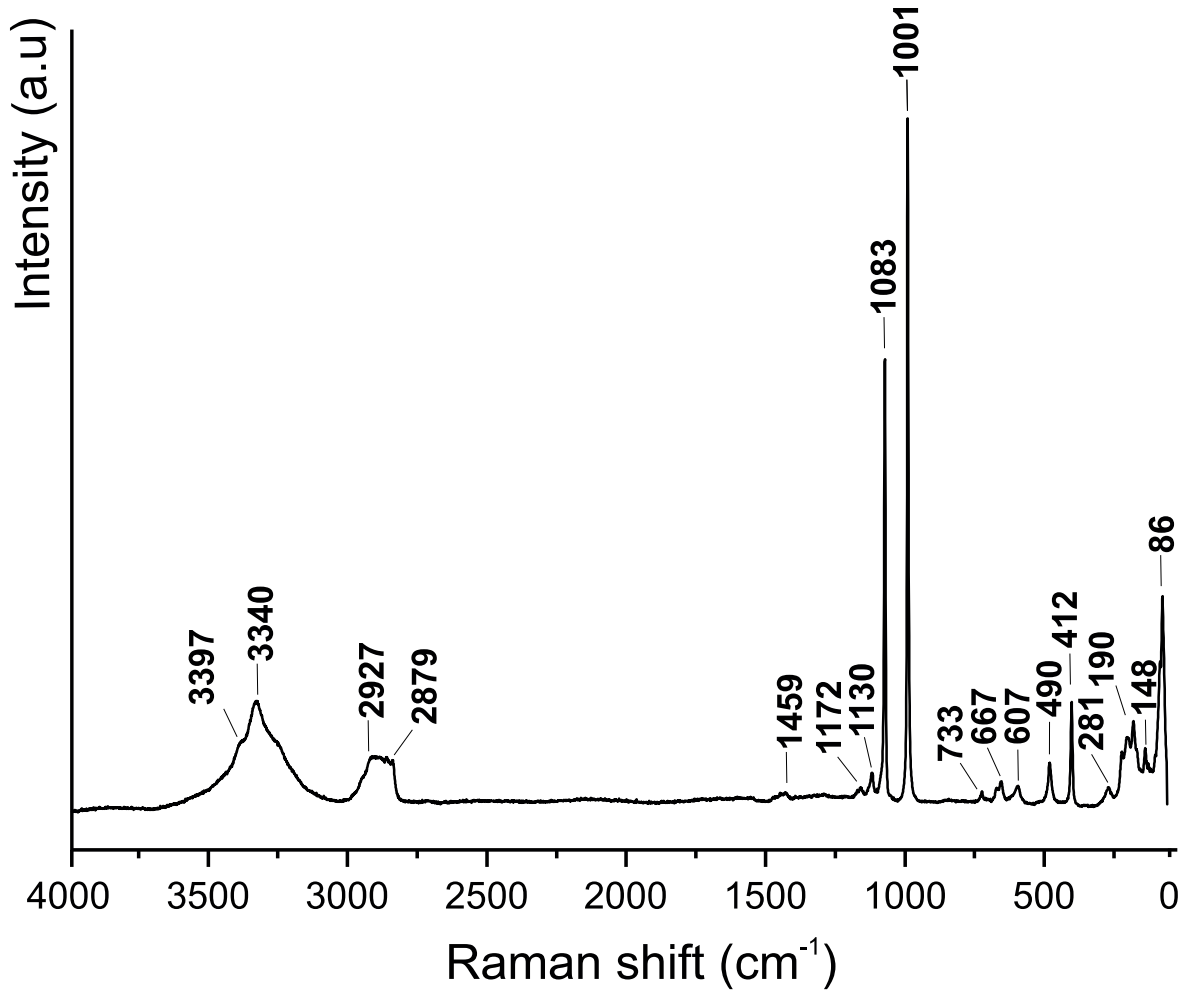

Fig. 3 Raman spectrum of 'korkinoite' $\left(4000-70 \mathrm{~cm}^{-1}\right)$.

and $\mathrm{Ca} 2$ sites are coordinated by three $\mathrm{O}$ atoms of sulfate groups, three $\mathrm{O}$ atoms of carbonate groups and two $\mathrm{O}_{\mathrm{wa}}$ atoms of $\mathrm{H}_{2} \mathrm{O}$ molecules each $(<\mathrm{Ca} 1-\mathrm{O}>2.353-2.679 \AA$, $<\mathrm{Ca} 1-\mathrm{O}_{\mathrm{Wa}}>2.416-2.455 \AA,<\mathrm{Ca} 2-\mathrm{O}>2.229-2.531 \AA$, $<\mathrm{Ca} 2-\mathrm{O}_{\mathrm{wa}}>2.439-2.488 \AA$ ). The $\mathrm{CaO}_{8}$ polyhedra share edges to form chains parallel to the $c$ axis connected by $\mathrm{CO}_{3}$ groups $(<\mathrm{C}-\mathrm{O}>1.270-1.294 \AA)$ and $\mathrm{SO}_{4}$ tetrahedra $(<\mathrm{S}-\mathrm{O}>1.464-1.487 \AA)$ to form two-dimensional layers. The layers are linked to each other along the $a$ axis via hydrogen bonds (Fig. 4). The bond-valence calculations allow identifying the Ow1-Ow4 as belonging to $\mathrm{H}_{2} \mathrm{O}$ molecules (Tab. 2). It should be noted that the quality of available crystals allowed to locate $\mathrm{H}$ atoms positions only with some restrictions, and DFIX restraint was used for refinement.

(a)

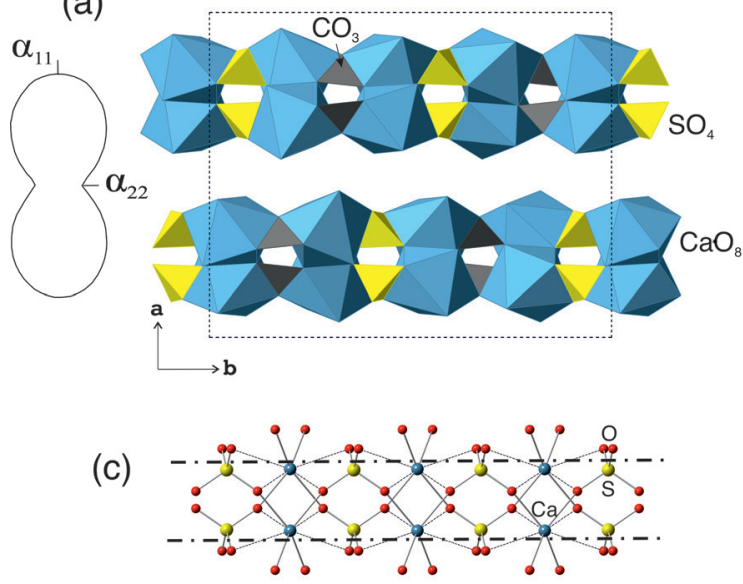

(b)

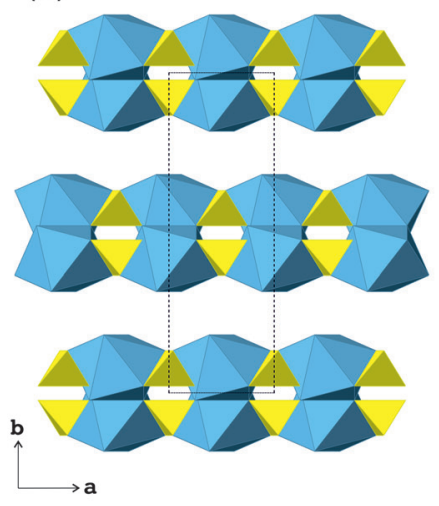

Cooper and Hawthorne (1996) and Hawthorne et al. (2000) noticed similarities between the crystal structures of rapidcreekite and gypsum, $\mathrm{Ca}\left(\mathrm{SO}_{4}\right) \cdot 2 \mathrm{H}_{2} \mathrm{O}$. Indeed, the chemical formula of rapidcreekite can be obtained by replacing half of the sulfate groups in gypsum with carbonate ions: $2 \mathrm{Ca}\left(\mathrm{SO}_{4}\right) \cdot 2 \mathrm{H}_{2} \mathrm{O}+\left(\mathrm{CO}_{3}\right)^{2-} \rightarrow \mathrm{Ca}_{2}\left(\mathrm{SO}_{4}\right)$ $\left(\mathrm{CO}_{3}\right) \cdot 4 \mathrm{H}_{2} \mathrm{O}+\left(\mathrm{SO}_{4}\right)^{2-}$. Fig. 4 shows the projection of the crystal structure of gypsum along the $c$ axis (Fig. 4b) compared to that of 'korkinoite' (rapidcreekite) (Fig. 4a). Both structures are layered. The layers in gypsum and 'korkinoite' are shown in Figs 5a and b, respectively. According to Cooper and Hawthorne (1996) and Hawthorne et al. (2000), the layer in rapidcreekite can be obtained from that in gypsum through the chemical twinning, where the twin plane runs through the $\mathrm{C}-\mathrm{O}$ bonds of triangular $\mathrm{CO}_{3}$ groups. The

Fig. 4 The crystal structure of 'korkinoite' (rapidcreekite). a - projected along the $\mathbf{c}$ axis with the section of the representation surface of the thermal expansion tensor at $200^{\circ} \mathrm{C} . \mathbf{b}-$ the crystal structure of gypsum projected along the $\mathbf{c}$ axis, and $\mathbf{c}-$ the projection of the hydrated $\mathrm{Ca}$ sulfate showing the core composition of the layers in between the dash-and-dot lines. Legend: $\mathrm{Ca}$ atoms and polyhedra $=$ blue; $\mathrm{S}$ atoms and polyhedra $=$ yellow; $\mathrm{CO}_{3}$ groups $=$ gray; $\mathrm{O}$ atoms $=$ red. Hydrogen atoms and hydrogen bonds are omitted for clarity. 
Fig. 5 The crystal structure of 'korkinoite' (rapidcreekite). a - the hydrated $\mathrm{Ca}$ sulfate layer in the crystal structure of gypsum and $\mathbf{b}$ - the hydrated $\mathrm{Ca}$ sulfate carbonate layer in the crystal structure of 'korkinoite' (rapidcreekite) as a chemically twinned derivative from the gypsum layer. The dash-and-dot lines in $\mathbf{5 b}$ outline the contours of gypsum modules. Legend as in Fig. 4.

(a)

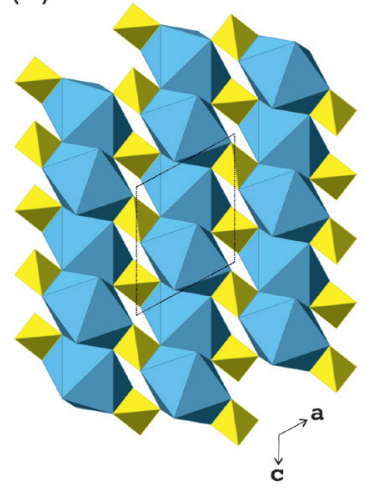

(b)

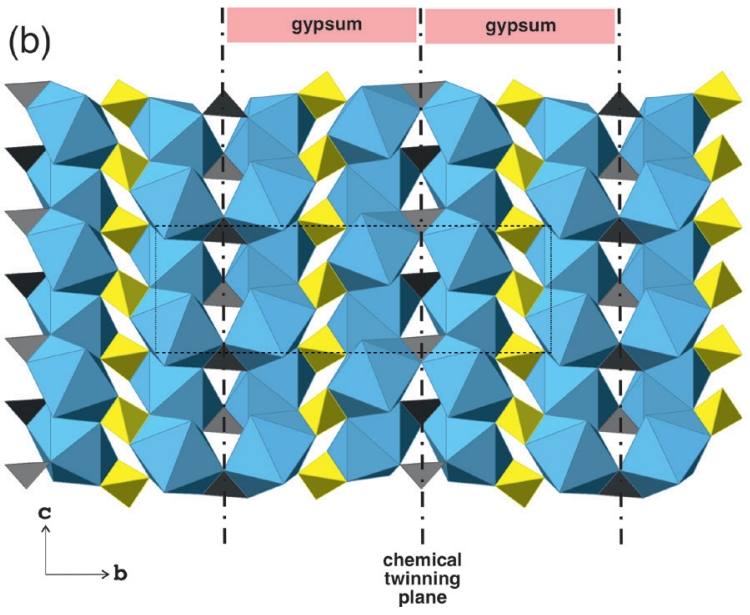

gypsum module consists of two monoclinic unit cells of gypsum doubled along the $a$ axis and is twinned so that the resulting structure adopts an orthorhombic symmetry. The twinning acts as a structure-building operator (Andersson and Hyde 1974) induced by replacing every second $\mathrm{SO}_{4}$ group with a $\mathrm{CO}_{3}$ triangle. As a result, the total information-based structural complexity (Krivovichev 2012, 2013) of rapidcreekite $(4.524 \mathrm{bit} / \mathrm{atom}$ and $832.335 \mathrm{bit} / \mathrm{cell}$ ) is almost an order of magnitude higher than that of gypsum (2.752 bit/atom and $66.039 \mathrm{bit} / \mathrm{cell})$.

\subsection{Thermal behaviour}

The crystal structure of 'korkinoite' is thermally stable up to $200^{\circ} \mathrm{C}$. At higher temperatures, the phase dehydrates and decomposes with the formation of calcium sulfate (after $500^{\circ} \mathrm{C}$ ) and calcium oxide (after $800^{\circ} \mathrm{C}$ ). The temperature dependences of the unit-cell parameters can be approximated by the following equations (Fig. 6): $a=15.4801+0.8 \times 10^{-3} \times T$; $b=19.2095+0.2 \times 10^{-3} \times T$; $c=6.1304+0.3 \times 10^{-3} \times T ;$ $V=1821.69+0.22 \times T$.

The values of the principal thermal expansion coefficients are approximately the same at room temperature and at $200^{\circ} \mathrm{C}\left(\times 10^{-6}{ }^{\circ} \mathrm{C}^{-1}\right)$ $\left(\alpha_{a}=53.7, \alpha_{b}=11.6 \alpha_{c}=52.0\right.$, $\alpha_{v}=117.3\left(25^{\circ} \mathrm{C}\right) ; \alpha_{a}=53.2$, $\alpha_{b}=11.6 \alpha_{c}=51.6, \alpha_{v}=116.4$ $\left(200^{\circ} \mathrm{C}\right)$. The thermal expansion is strongly anisotropic in the $a b$ and $b c$ planes, whereas it is practically isotropic in the $a c$ plane. Considering the layered

Fig. 6 Temperature dependence of the unit-cell parameters of 'korkinoite'.

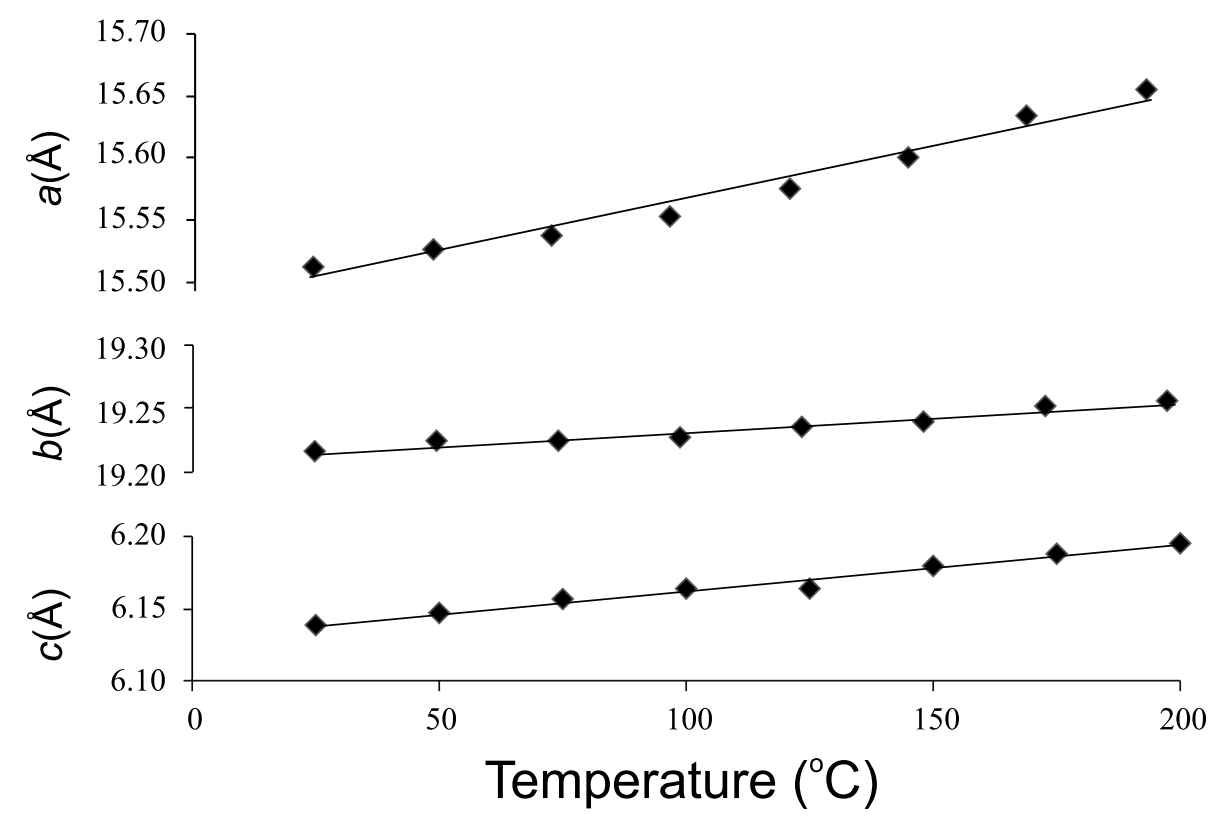




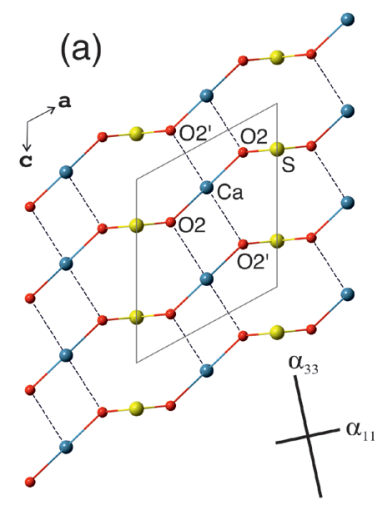

(b)

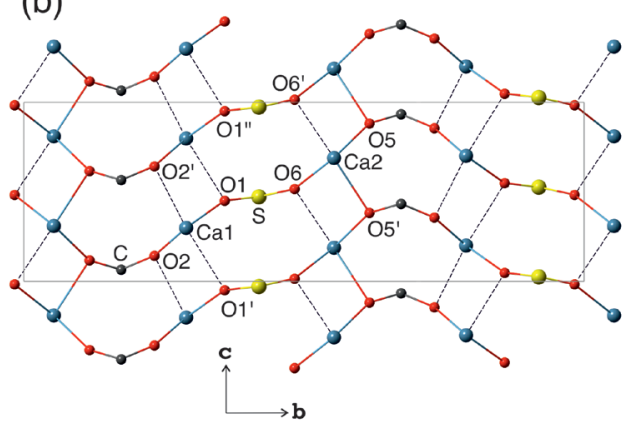

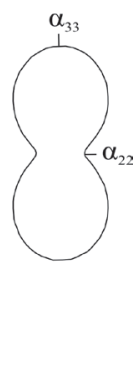

Fig. 7 a - the core atomic sheet of the hydrated Ca sulfate layer in the crystal structure of gypsum and $\mathbf{b}$ - the core atomic sheet of the hydrated $\mathrm{Ca}$ sulfate carbonate layer in the crystal structure of 'korkinoite'(rapidcreekite) together with the section of the representation surface of the thermal expansion tensor at $200^{\circ} \mathrm{C}$. Legend as in Fig. 4; $\mathrm{C}$ atoms $=$ gray. ues: $\alpha_{11}=1.2(6), \alpha_{22}=36.82(1), \alpha_{33}=25.1(5)\left(\times 10^{-6}{ }^{\circ} \mathrm{C}^{-1}\right)$, $\alpha_{22} \| \mathbf{b}, \alpha_{33} \wedge \mathbf{c} \sim 11.8^{\circ}$. The expansion coefficients along the crystallographic axes were reported by Schofield et al. (1996) as $\alpha_{a}=3.98, \alpha_{b}=43.6 \alpha_{c}=25.3\left(\times 10^{-6}{ }^{\circ} \mathrm{C}^{-1}\right)$, whereas Ballirano and Melis (2009) obtained slightly higher values: $\alpha_{a}=4.29, \alpha_{b}=49.4 \alpha_{c}=29.7\left(\times 10^{-6}{ }^{\circ} \mathrm{C}^{-1}\right)$. In any case, the highly anisotropic expansion was observed within the hydrated Ca sulfate layers by analogy with the hydrated $\mathrm{Ca}$ sulfate carbonate layers in rapidcreekite. In order to explain these observations, Knight et al. (1999) proposed that '...the dominant structural feature in the magnitudes and orientation of the thermal expansion tensors $\alpha_{11}$ and $\alpha_{33}$ are the sulphate tetrahedra, with the expansion of $\mathrm{S}-\mathrm{O}(2)$ and $\mathrm{O}(2)-\mathrm{O}\left(2^{\prime}\right)$ resulting in $\alpha_{11}$ being significantly larger than $\alpha_{33}$, which is limited by the contraction of $\mathrm{S}-\mathrm{O}(1)$ and $\mathrm{O}(1)-\mathrm{O}\left(1^{\prime}\right)$.' However, the situation is exactly the opposite: $\alpha_{33}$ is significantly larger than $\alpha_{11}$ and not the vice versa. More reasonable explanation was proposed by Ballirano and Melis (2009), who pointed out that the Ca-O2" distance is the longest in the $\mathrm{CaO}_{8}$ polyhedron and 'regularly increases as a function of temperature'. Indeed, if the layer of gypsum is cut as shown by the dot-and-dash lines in Fig. $4 \mathrm{c}$, one obtains the core atomic sheet of the $\mathrm{O}$ atoms and cations shown in Fig. 7a. As can be seen from the diagram, the $\mathrm{Ca}-\mathrm{O} 2$ ' bond is almost parallel to the direction of $\alpha_{33}$ and this bond increases essentially under thermal treatment as demonstrated by the structure refinements at different temperatures (Schofield et al. 1996, 1997, 2000; Knight et al. 1999; Ballirano and Melis 2009). If the $\left[\mathrm{Ca}_{4}\left(\mathrm{SO}_{4}\right)\left(\mathrm{CO}_{3}\right)\right.$ $\left.\left(\mathrm{H}_{2} \mathrm{O}\right)_{4}\right]$ layer in rapidcreekite is cut similarly, the distribution of the chemical bonds within the obtained atomic sheet (Fig. 7b) is somewhat similar to that observed in gypsum. The short $\mathrm{Ca}-\mathrm{O}$ bonds are (in average) oriented along the $b$ axis $(\mathrm{Ca} 1-\mathrm{O} 1=2.353, \mathrm{Ca} 1-\mathrm{O} 2=2.373, \mathrm{Ca} 2-\mathrm{O} 5=2.299$, $\mathrm{Ca} 2-\mathrm{O} 6=2.416 \AA$ ), whereas the longer $\mathrm{Ca}-\mathrm{O}$ bonds are (in average) parallel to the $c$ axis $\left(\mathrm{Ca} 1-\mathrm{O} 1^{\prime}=2.679, \mathrm{Ca} 1-\mathrm{O} 2\right.$ ' $=2.497, \mathrm{Ca} 2-\mathrm{O}^{\prime}{ }^{\prime}=2.415, \mathrm{Ca} 2-\mathrm{O}^{\prime}{ }^{\prime}=2.530 \AA$ ) . Therefore, the [001] direction is much 'softer' than the [100] direction is, therefore, is more prone to the influence of temperature. One may conclude that the observed anisotropies of thermal expansion in gypsum and rapidcreekite have the same crystal chemical nature. However, more detailed studies of the crystal structure of rapidcreekite under different temperatures are needed to confirm this suggestion.

\section{Conclusions}

The current study of the crystal structure, thermal behavior and vibrational spectroscopy of 'korkinoite' confirms that it is fully identical to rapidcreekite. Both 'korkinoite' (technogenic rapidcreekite) and rapidcreekite are structurally related to gypsum through the unit-cell twinning induced by replacing one-half of sulfate groups in gypsum by carbonate ions. The structural relations determine the similarity of thermal behavior of gypsum and rapidcreekite with strongly anisotropic expansion within the sheet of Ca polyhedra and sulfate (gypsum) or sulfate and carbonate (rapidcreekite) groups.

Acknowledgments. The X-ray diffraction studies have been performed in the X-ray Diffraction Resource Centre and the Centre for Geo-Environmental Research and Modelling of St. Petersburg State University. We are grateful to reviewers and the handling editor for their constructive and valuable remarks. The study was supported by the Russian Foundation for Basic Research (grant No. 19-05-00628 to M.S.A., A.A.Z., A.A.Z., M.A.R) and the Russian President grant for leading scientific schools (\# NSh-2526.2020.5 to S.V.K., M.G.K.).

Electronic supplementary material. Supplementary material consisting of crystal structure data (cif) are available online at the Journal website (http://dx.doi.org/10.3190/ jgeosci.327).

\section{References}

Andersson S, Hyde BG (1974) Twinning on the unit cell level as a structure-building operation in the solid state. J Solid State Chem 9: 92-101 
Avdontceva MS, Zolotarev AA Jr, Krivovichev SV, Krzhizhanovskaya MG, SoKol EV, KoKh SN, Bocharov VN, RasSOMAKHIN MA, ZOLOTAREV AA (2021) Fluorellestadite from burned coal dumps: crystal structure refinement, vibrational spectroscopy data and thermal behavior. Mineral Petrol 115: 271-281

Ballirano P, Melis E (2009) Thermal behaviour and kinetics of dehydration of gypsum in air from in situ real-time laboratory parallel-beam X-ray powder diffraction. Phys Chem Miner 36: 391-402

Bindi L, Bonazzi P, Dei L, Zoppi A. (2005) Does the bazhenovite structure really contain a thiosulfate group? A structural and spectroscopic study of the sample from the type locality. Amer Miner 90: 1556-1562

Brese NE, O'KeEFFe M (1991) Bond-valence parameters for solids. Acta Crystallogr B47: 192-197

BRUKER-AXS Topas V4.2 (2009) General profile and structure analysis software for powder diffraction data. Karlsruhe, Germany

BROOKER MH, TAYLOR PS, LOPATA VJ (1983) Infrared and Raman spectra and X-ray diffraction studies of solid lead (II) carbonates. Can J Chem 61: 494-502

Chesnokov BV, Bazhenova LF (1985) Srebrodolskite $\mathrm{Ca}_{2} \mathrm{Fe}_{2} \mathrm{O}_{5}-\mathrm{a}$ new mineral. Zap Vsesojuz mineral Obšč 114: 195-199 (in Russian)

Chesnokov BV, Polyakov VO, Bushmakin, AF (1987a) Bazhenovite $\mathrm{CaS}_{5} \cdot \mathrm{CaS}_{2} \mathrm{O}_{3} \cdot 6 \mathrm{Ca}(\mathrm{OH})_{2} \cdot 20 \mathrm{H}_{2} \mathrm{O}-\mathrm{A}$ new mineral. Zap Vsesojuz mineral Obšč 116: 737-743 (in Russian)

Chesnokov BV, Bazhenova LF, Bushmakin AF (1987b) Fluorellestadite $\mathrm{Ca}_{10}\left[\left(\mathrm{SO}_{4}\right),\left(\mathrm{SiO}_{4}\right)\right]_{6} \mathrm{~F}_{2}-$ a new mineral. Zap Vsesojuz mineral Obšč 116: 743-746 (in Russian)

Chesnokov BV, Lotova EV, Pavlyuchenko VS, Usova LV, Bushmakin AF, Nishanbayev TP (1989) Svyatoslavite $\mathrm{CaAl}_{2} \mathrm{Si}_{2} \mathrm{O}_{8}$ (orthorhombic) - A new mineral. Zap Vsesojuz mineral Obšč 118:111-114 (in Russian)

Chesnokov BV, Lotova EV, Nigmatullina EN, PavLUTCHENKO VS, BUSHMAKIN AF (1990a) Dmisteinbergite $\mathrm{CaAl}_{2} \mathrm{Si}_{2} \mathrm{O}_{8}$ (hexagonal) - A new mineral. Zap Vsesojuz mineral Obšč 119: 43-46 (In Russian)

Chesnokov BV, Nishanbaev TP, Bazhenova LF (1990b) Rorisite $\mathrm{CaFCl}$ - a new mineral. Zap Vsesojuz mineral Obšč 119:7 3-76 (In Russian)

Chesnokov BV, Bazhenova LF, Bushmakin AF, KotLyarov VA, Belogub EV (1995) New minerals from burnt dumps of the Chelyabinsk coal basin (communication seven). Ural Mineral Sb 4: 3-28 (In Russian)

Chesnokov BV, Shcherbakova EP, Nishanbaev TP (2008) Minerals from Burned Dumps of Chelyabinsk Coal Basin; Institute of Mineralogy UrO RAS: Miass, Russia (in Russian)

COOPER MA, HAWTHORne FC (1996) The crystal structure of rapidcreekite, $\mathrm{Ca}_{2}\left(\mathrm{SO}_{4}\right)\left(\mathrm{CO}_{3}\right)\left(\mathrm{H}_{2} \mathrm{O}\right)_{4}$, and its relation to the structure of gypsum. Canad Mineral 34: 99-106
CrysAlisPro Software System, version 1.171.39.44 (2015) Rigaku Oxford Diffraction: Oxford, UK

D’Angeli IM, De Waele J, Fiorucci A, Vigna B, BerNASCONI SM, Florea LJ, Liso IS, PARISE M (2021) Hydrogeology and geochemistry of the sulfur karst springs at Santa Cesarea Terme (Apulia, southern Italy). Hydrol J 29: 481-498

De Waele J, Audra P, Madonia G, Vattano M, Plan L, D'ANgeli IM, Bigot JY, Nobécourt JC (2016) Sulfuric acid speleogenesis (SAS) close to the water table: Examples from southern France, Austria, and Sicily. Geomorphology 253: 452-467

Dolomanov OV, Bourhis LJ, Gildea RJ, Howard JAK, PUSCHMANN H (2009) OLEX2: A complete structure solution, refinement and analysis program. J Appl Crystallogr 42: 339-341

FizeAU H (1868) Ueber die Ausdehnung starrer Koerper Zweite. Ann Phys 135: 372-395

Frezzotti ML, Tecce F, CASAgli A (2012) Raman spectroscopy for fluid inclusion analysis. J Geochem Explor 112: $1-20$

Gaskova OL, Boguslavsky AE, Shemelina OV (2015) Uranium release from contaminated sludge materials and uptake by subsurface sediments: Experimental study and thermodynamic modeling. Appl Geochem 55: 152-159

Hawthorne FC, Krivovichev SV, Burns PC (2000) The crystal chemistry of sulfate minerals. Rev Mineral Geochem 40: 1-112

IbáÑez-Insa J, Elvira JJ, LlovetX, Perez-Cano J, Oriols N, Busquets-Maso M, Hernandez S (2017) Abellaite, $\mathrm{NaPb}_{2}\left(\mathrm{CO}_{3}\right)_{2}(\mathrm{OH})$, a new supergene mineral from the Eureka mine, Lleida province, Catalonia, Spain. Eur J Mineral 29: 915-922

KNight KS, Stretton IC, SCHOField PF (1999) Temperature evolution between $50 \mathrm{~K}$ and $320 \mathrm{~K}$ of the thermal expansion of gypsum derived from neutron powder diffraction data. Phys Chem Miner 26: 477-483

KrIVOVICHEv SV (2012) Topological complexity of crystal structures: quantitative approach. Acta Crystallogr A68: 393-398

KRIVOVICHEV SV (2013) Structural complexity of minerals: information storage and processing in the mineral world. Mineral Mag 77: 275-326

KrivovicheV SV, SHCHERBAKova EP, NishaNBAEV TP (2012) The crystal structure of svyatoslavite and evolution of complexity during crystallization of a $\mathrm{CaAl}_{2} \mathrm{Si}_{2} \mathrm{O}_{8}$ melt: A structural automata description. Canad Mineral 50: 585-592

Kruszewski Ł, Świerk M, Siuda R, Szelęg E, MarciNIAK-MALISZEwSKA B (2020) Third worldwide occurrence of juangodoyite, $\mathrm{Na}_{2} \mathrm{Cu}\left(\mathrm{CO}_{3}\right)_{2}$, and other secondary $\mathrm{Na}, \mathrm{Cu}, \mathrm{Mg}$, and $\mathrm{Ca}$ minerals in the fore-sudetic monocline (Lower Silesia, SW Poland). Minerals 10: 190

LaNe MD (2007) Mid-infrared emission spectroscopy of sulfate and sulfate-bearing minerals. Amer Miner 92: 1-18 
LANGREITER T, KAHLENBERG V (2015) TEV - a program for the thermal expansion tensor Crystals 5: 143-153

Lau GE, Cosmidis J, Grasby SE, Trivedi CB, Spear JR, TEMPLETON AS (2017) Low-temperature formation and stabilization of rare allotropes of cyclooctasulfur $\left(\beta-\mathrm{S}_{8}\right.$ and $\gamma-S_{8}$ ) in the presence of organic carbon at a sulfurrich glacial site in the Canadian High Arctic. Geochim Cosmochim Acta 200: 218-231

MartíneZ-Ramírez S, FernándeZ-Carrasco L (2012) Carbonation of ternary cement systems. Constr Build Mater 27:313-318

OnAC BP, EFFEnberger HS, Wynn JG, PovarĂ (2013) Rapidcreekite in the sulfuric acid weathering environment of Diana Cave, Romania. Amer Miner 98: 1302-1309

PARAFINIUK J, HATERT F (2020) New IMA CNMNC guidelines on combustion products from burning coal dumps. Eur J Mineral 32: 215-217

Roberts AC, Ansell HG, Jonasson IR (1986) Rapidcreekite, a new hydrated calcium sulfate-carbonate from the Rapid Greek Area, Yukon Territory. Canad Mineral 24: 51-54

Schofield PF, Knight KS, Stretton IC (1996) Thermal expansion of gypsum investigated by neutron powder diffraction. Amer Miner 81: 847-851

Schofield PF, Stretton IC, Knight KS, Hull S (1997) Powder neutron diffraction studies of the thermal expansion, compressibility and dehydration of deuterated gypsum. Physica B 234-236: 942-944

Schofield PF, Wilson CC, Knight KS, Stretton IC (2000) Temperature related structural variation of the hydrous components in gypsum. Z Kristallogr 215: 707-710

Shcherbakova EP, Bazhenova LF (1989) Efremovite $\left(\mathrm{NH}_{4}\right)_{2} \mathrm{Mg}_{2}\left(\mathrm{SO}_{4}\right)_{3}-$ Ammonium analogue of langbeinite - A new mineral. Zap Vsesojuz mineral Obšč 118: 84-87 (in Russian)

Shcherbakova EP, Bazhenova LF, Chesnokov BV (1988) Godovikovite - $\mathrm{NH}_{4}(\mathrm{Al}, \mathrm{Fe})\left(\mathrm{SO}_{4}\right)_{2}$ a new ammoniumbearing sulfate. Zap Vsesojuz Mineral Obšč 117:208-211 (in Russian)

SHELDRICK GM (2015) Crystal structure refinement with SHELXL. Acta Crystallogr C71: 3-8
Situm A, Beam JC, Hughes KA, Rowson J, EssilfieDughan J, Crawford A, Grosvenor AP (2020) An $\mathrm{X}$-ray spectromicroscopy study of the calcium mineralization in the JEB tailings management facility at McClean Lake, Saskatchewan. Appl Geochem 112: 104459

Warchulski R, Gaweda A, KadZiołka-GaWeŁ M, Szopa $\mathrm{K}$ (2015) Composition and element mobilization in pyrometallurgical slags from the Orzeł Biały smelting plant in the Bytom-Piekarylaskie area, Poland. Mineral Mag 79: 459-483

Wen H, Xu W, Li Y, You Y, Luo X (2020) Siliceoussulphate rock coatings at Zhenzhu Spring, Tengchong, China: The integrated product of acid-fog deposition, spring water capillary action, and dissolution. Geol Mag 157: 201-212

Zhernovsky IV, Kozhukhova NI, Cherevatova AV, RAKHIMBAEV ISH, ZHERNOVSKAYA IV (2016) New data about nano-sized phase formation in binding system "gypsum - lime". Stroit Mater 7: 9-12 (in Russian)

Zolotarev AA, Krivovichev SV, Panikorovskit TL, Gurzhiy VV, Bocharov VN, Rassomakhin MA (2019a) Dmisteinbergite, $\mathrm{CaAl}_{2} \mathrm{Si}_{2} \mathrm{O}_{8}$, a Metastable Polymorph of Anorthite: Crystal-Structure and Raman Spectroscopic Study of the Holotype Specimen. Minerals 9(10): 570

Zolotarev AA, Zhitova ES, Krzhizhanovskaya MG, RASSOMAKHIN MA, SHILOVSKIKH VV, KRIVOVICHEV SV (2019b) Crystal chemistry and high-temperature behaviour of ammonium phases $\mathrm{NH}_{4} \mathrm{MgCl}_{3} \cdot 6 \mathrm{H}_{2} \mathrm{O}$ and $\left(\mathrm{NH}_{4}\right)_{2} \mathrm{Fe}^{3+} \mathrm{Cl}_{5} \cdot \mathrm{H}_{2} \mathrm{O}$ from the burned dumps of the Chelyabinsk Coal Basin. Minerals 9(8): 486

Zolotarev AA, Krivovichev SV, Avdontceva MS, Shilovskikh VV, Rassomakhin MA, YAPAsKurt VO, PeKov IV (2020) Crystal chemistry of alkali-aluminum-iron sulfates from the burnt mine dumps of the Chelyabinsk Coal Basin, South Urals, Russia. Crystals 10(11): 1062

Zolotarev AA, Krivovichev SV, Avdontceva MS, Zhitova ES, Shchipalkina NV, PeKov IV (2021) Crystal chemistry of "Malakhovite", an anthropogenic analog of khesinite from burnt dumps of the Chelyabinsk Coal Basin (South Urals). Crystallogr Rep 66: 66-75 